\title{
IDENTIFIKASI JAMUR Candida sp.PADA RONGGA MULUT PEROKOK AKTIF DI RW 09 KOMPLEK KOPERASI CURUG CIMANGGIS DEPOK
}

\author{
Mulyati ${ }^{1)},{ }^{*}$ Catu Umirestu Nurdiani, ${ }^{2)}$ Widianti Safitri ${ }^{2)}$ \\ ${ }^{1}$ Laboratorium Parasitologi Fakultas Kedokteran Universitas Indonesia \\ ${ }^{2}$ Program Studi Analis Kesehatan, Fakultas Kesehatan, Universitas Mohammad Husni Thamrin \\ Correspondence author:Catu Umirestu Nurdiani, ctani_enan@yahoo.com, Jakarta, Indonesia
}

\begin{abstract}
ABSTRAK
Jamur Candida $s p$ merupakan jamur yang terdapat di rongga mulut manusia yang akan menimbulkan suatu kelainan apabila ada faktor resiko. Faktor resiko dapat meningkatkan pertumbuhan koloni Candida sp dan mempermudah invasi jamur tersebut masuk kedalam jaringan, sehingga terbentuk kolonisasi dan keluhan. Salah satu faktor resiko tumbuhnya Candida $s p$ adalah merokok. Tujuan penelitian ini untuk mengetahui keberadaan Candida $s p$ pada rongga mulut perokok aktif di RW09 Komplek Koperasi Curug Cimanggis Depok. Bahan Pemeriksaan Swab rongga mulut dengan jumlah sampel yang diperiksa adalah 66 sampel. Pemeriksaan ini menggunakan 2 metode yaitu pemeriksaan langsung dan biakan SDA+. Berdasarkan hasil pemeriksaan langsung dari 66 responden didapatkan sel ragi sebanyak 65,1\% (43/66) dan tidak ditemukan elemen jamur sebanyak 34,9\% (23/66). Pada biakan SDA+ didapatkan 69,6\% (46/66) sampel tumbuh koloni Candida sp, non Candida $s p$ sebanyak 30,4\% (20/66). Berdasarkan lamanya konsumsi rokok yang mengkonsumsi rokok $>1$ tahun didapatkan positif Candida 48,4\%, <1 tahun didapatkan positif candida 21,2\%. Berdasarkan banyaknya konsumsi rokok yang mengkonsumsi 1 batang perhari didapatkan positif Candida sebanyak $16,6 \%$ dan $>1$ batang perhari didapatkan positif Candida Sebanyak 53,0\%. Berdasarkan perilaku menyikat gigi yang menyikat gigi 1x didapatkan positif Candida sebanyak 51,5\% dan 2x sehari didapatkan positif Candida $18,1 \%$. Berdasarkan keluhan yang memiliki keluhan didapatkan positif Candida sebanyak $50 \%$ dan yang tidak memiliki keluhan didapatkan positif Candida sebanyak 19,6\%. Dari hasil penelitian disimpulkan bahwa dari 66 sampel diperoleh 69,6\% infeksi Candida sp. Terdapat hubungan bermakna antara lamanya mengkonsumsi rokok, banyaknya rokok yang dikonsumsi, perilaku menyikat gigi, keluhan yang terjadi dengan keberasaan jamur Candida $s p(\mathrm{p}<0,05)$.
\end{abstract}

Kata kunci : Candida $s p$, perokok

\section{ABSTRACT}

Candida sp in the oral cavity of active smokers in RW09 Curug Cimanggis Depok Cooperative Complex. Material for Examination Oral swabs with the number of samples examined were 66 samples. This examination uses 2 methods, namely direct examination and culture of SDA +. Based on the results of direct examination of 66 respondents, it was found that yeast cells were 65.1\% (43/66) and no fungal elements were found as much as 34.9\% (23/66). In SDA + cultures, 69.6\% (46/66) of samples grew 30.4\% (20/66) of Candida sp and nonCandida sp colonies. Based on the length of time consuming cigarettes who consume cigarettes $>1$ year, it is found positive for Candida 48.4\%, <1 year is obtained positive for candida $21.2 \%$. Based on the number of cigarette consumption that consumes 1 stick per day, Candida is positive as much as $16.6 \%$ and $>1$ cigarette per day is positive for Candida as much as $53.0 \%$. Based on the behavior of brushing teeth, brushing teeth once was positive Candida was $51.5 \%$ and $2 x$ a day was Candida positive 18.1\%. Based on complaints who have complaints, it is found positive for Candida as much as $50 \%$ and those who have no complaints are obtained positive for Candida as much as $19.6 \%$. From the results of the study it was concluded that from 66 samples, $69.6 \%$ of Candida sp. There was a significant relationship between the duration of consuming cigarettes, the number of cigarettes consumed, the behavior of brushing teeth, the complaints that occurred with the presence of the fungus Candida $s p(p<0.05)$.

Keyword : Candida sp, Smokers.

Open Journal System (OJS): journal.thamrin.ac.id 


\section{PENDAHULUAN}

Indonesia menempati urutan ketiga dari sepuluh Negara yang merupakan Negara dengan proporsi perokok tertinggi di dunia. Hasil riset Kesehatan Dasar (Riskesdas) tahun 2010 sampai 2013 menunjukkan bahwa prevalensi jumlah perokok di Indonesia semakin meningkat dari tahun ke tahun. Pada tahun 2007, rata-rata jumlah perokok Indonesia adalah 34,7\% (65,9\% laki-laki dan 4,2\% perempuan) meningkat menjadi 36,3\% (68,8\% laki laki dan 6,9\% perempuan). Proposi terbanyak perokok aktif setiap hari pada umur 30-34 tahun sebesar 33,4\% dengan rata-rata rokok yang dikonsumsi per harinya sebesar 12,3 batang (setara satu bungkus rokok). (WHO, 2008)

Merokok tidak hanya menimbulkan efek secara sistemik, tetapi juga dapat menyebabkan timbulnya kondisi patologis di rongga mulut. Gigi dan jaringan lunak rongga mulut, merupakan bagian yang dapat mengalami kerusakan akibat rokok. (Warnakulasuriya S, 2010). Flora normal adalah mikroorganisme yang dianggap tidak berbahaya, Pada rongga mulut terdapat banyak flora normal dalam keadaan tidak menimbulkan penyakit, namun bila terjadi gangguan sistem imun maupun perubahan keseimbangan flora normal rongga mulut maka flora normal tersebut dapat menjadi patogen. Dalam hal ini beberapa flora normal rongga mulut salah satunya adalah candida. (Kuswadji, 2006). Candidiasis merupakan infeksi oportunistik tertinggi pada ODHA yakni 31,29\%. Kasus candidiasis oral juga terjadi pada orang sehat dengan penurunan respon imun yang disebabkan oleh beberapa faktor seperti kelainan endokrin, malnutrisi, protesa gigi, gangguan epitel, diet tinggi karbohidrat, bayi dan lansia, kebersihan mulut yang buruk, dan perokok . (Ditjen P2P 2005)

Continuing Education (1992) mengatakan bahwa sebagian besar pasien (83\%) dengan candidiasis oral rata-rata perokok sedang dan berat. faktor resiko lokal yang berhubungan dengan peningkatan prevalensi candidiasis oral dan kariernya adalah serostomia, perokok, pemakai gigi tiruan, dan kebersihan rongga mulut yang buruk. (Calcaterra 2013).

Merokok, baik itu disertai kombinasi dengan faktor lain atau tidak, mungkin menjadi faktor predisposisi penting dalam kejadian candidiasis oral, meskipun hubungan atau patogenesisnya terhadap candida rongga mulut masih jauh dari pemecahannya. (Ellepola 2005)

Iritasi yang terus menerus dari hasil pembakaran tembakau menyebabkan penebalan pada jaringan mukosa mulut. Sebelum gejala klinis terlihat, iritasi dari asap tembakau ini menyerang sel-sel epitel mukosa sehingga aktifitasnya meningkat. Gejala ini baru terlihat bila aktifitas selluler bertambah dan epitel menjadi tebal, terutama tampak pada mukosa bukal (mukosa yang menghadap pipi) dan pada dasar mulut. Perubahan mukosa mulut terlihat sebagai bercak putih. Bercak putih tersebut mungkin disebabkan karena epitel yang tebal jenuh dengan saliva (air ludah). Oleh karena itu hal yang ditimbulkan tersebut dapat berpotensi menimbulkan tumbuhnya jamur pada mulut perokok aktif. (Mulyawati Y, 2009). Dari Penelitian sebelumnya oleh Puteri Ridha Ramadhani pada tahun 2017 Open Journal System (OJS): journal.thamrin.ac.id http://journal.thamrin.ac.id/index.php/anakes/issue/view/33 
positif Candida pada 57 sampel sebanyak (87,7\%). Wilayah RW 09 di Komplek Koperasi Curug Cimanggis Depok, terdapat 200 kepala rumah tangga . Berdasarkan pengamatan yang dilakukan peneliti kondisi disekitar komplek memperlihatkan banyaknya warga yang mengkonsumsi rokok mulai dari remaja hingga orang tua, sehingga peneliti tertarik untuk melakukan pemeriksaan rongga mulut terhadap adanya Jamur Candida sp.

Berdasarkan hal tersebut, penulis ingin meneliti “Candida sp pada rongga mulut perokok aktif di RW 09 Komplek Koperasi Curug, Cimanggis Depok “ untuk mengetahui infeksi Candida sp Pada rongga mulut perokok aktif.

\section{METODE}

Tempat pengambilan sampel dilakukan di komplek koperasi RW 09 dan penelitian dilakukan di Laboratorium Biologi Universitas MH Thamrin Jakarta. Waktu penelitian 25 juli-5 Agustus. Populasi dari penelitian ini adalah seluruh warga di RW09 Komplek Koperasi Curug Cimanggis Depok yang mengkonsumsi rokok, sedangkan sampelnya adalah warga di RW09 Komplek Koperasi Curug Cimanggis Depok yang merupakan perokok aktif sebanyak 66 orang. Melakukan pendataan warga perokok aktif di RW 09 komplek koperasi Menetapkan perokok aktif yang bersedia di ambil swab rongga mulutnya Pemberian penjelasan atau informasi kepada warga yang merupakan perokok akitf yang akan dimintai sampel dan memberikan lembar kuisioner. Untuk mendapatkan Candida $s p$ yang berada di dalam rongga mulut, maka bahan klinik yang dijadikan sampel adalah swab rongga mulut) perokok aktif . Cairan di rongga mulut diambil dengan cara menghapuskan swab steril ke seluruh permukaan mukosa rongga mulut kemudian swab tersebut dimasukkan ke dalam tabung yang berisi $1 \mathrm{ml}$ larutan garam fisiologis . kemudian dilakukan pemeriksaan langsung dan pemeriksaan Biakan.

\section{HASIL \& PEMBAHASAN}

Jumlah sampel Swab Rongga Mulut Perokok Aktif Di RW 09 Komplek Koperasi Curug Cimanggis Depok di dalam penelitian ini berjumlah 66 sampel, selanjutnya dilakukan pemeriksaan langsung dengan $\mathrm{Nacl} 0,9 \%$ didapatkan hasil seperti yang tercantum pada tabel 1: 


\section{Tabel 1}

Hasil Pemeriksaan Langsung (Nacl 0,9 \%) Pada Sampel Swab Rongga Mulut Perokok Aktif Di RW 09 Komplek Koperasi Curug Cimanggis Depok

\begin{tabular}{lcc}
\hline Elemen jamur & $\begin{array}{c}\text { Jumlah hasil pemeriksaan } \\
\text { secara langsung }\end{array}$ & $\%$ \\
\hline Sel Ragi & 43 & $65,1 \%$ \\
Hifa semu & 0 & $0 \%$ \\
Tanpa elemen jamur & 23 & $34,9 \%$ \\
\hline \multicolumn{1}{c}{ Jumlah } & 66 & $100 \%$ \\
\hline
\end{tabular}

Sumber: Safitri W, 2018

Pada tabel 1 dapat diketahui bahwa ditemukan elemen jamur pada swab rongga mulut perokok aktif di RW 09 Komplek Kopersi Curug Cimanggis Depok Pada pemeriksaan langsung didapatkan elemen jamur sel ragi sebanyak 43 sampel $(65,1 \%)$ tidak ditemukan hifa semu $0 \%$ dan tanpa elemen jamur sebanyak 23 sampel $(34,9 \%)$.

Hasil Pemeriksaan Biakan pada 66 sampel swab rongga mulut perokok aktif di RW09 Komplek Kopersi Curug Cimanggis Depok berdasarkan pemeriksaan biakan didapatkan hasil seperti yang tercantum pada tabel 2:

Tabel 2

Hasil Pemeriksaan Candida sp. Pada Sampel Swab Rongga Mulut Perokok Aktif Di RW 09 Komplek Koperasi Curug Cimanggis Depok

Berdasarkan Biakan Media SDA (+)

\begin{tabular}{|c|c|c|}
\hline $\begin{array}{l}\text { Jenis jamur yang } \\
\text { Ditemukan }\end{array}$ & Hasil pemeriksaan & $\%$ \\
\hline Candida $s p$ & 46 & $69,6 \%$ \\
\hline (Non Candida sp) & 20 & $30,4 \%$ \\
\hline Jumlah & 66 & \\
\hline
\end{tabular}

Berdasarkan tabel di atas dapat dilihat bahwa ditemukan berbagai jenis jamur dari sampel swab rongga mulut perokok aktif di RW09 Komplek Kopersi Curug Cimanggis Depok yang dibiakan pada media SDA(+) yaitu Candida sp 46 koloni (69,6\%), dan non Candida sp 20 koloni (30,4\%). 
Pada biakan SDA+ yang sudah ditumbuhi koloni Candida sp kemudian dilakukan penghitungan jumlah koloni untuk melihat kepadatan koloni yang tercantum pada table 3 :

\section{Tabel 3}

\section{Persentase Candida pada 46 Biakan Swab Rongga Mulut Perokok Aktif di Komplek Koperasi Curug Cimanggis Depok Berdasarkan kepadatan koloni}

\begin{tabular}{ccc}
\hline Kepadatan Koloni & Jumlah & $\%$ \\
\hline+ (1-50 koloni) & 9 & $19,5 \%$ \\
$++(\mathbf{5 0 - 1 0 0}$ koloni) & 14 & $30,4 \%$ \\
$+++(>\mathbf{1 0 0}$ koloni) & 23 & $50,1 \%$ \\
\hline Jumlah & 46 & $100 \%$ \\
\hline
\end{tabular}

Berdasarkan table diatas dapat diketahui kepadatan koloni pada 46 sampel biakan Candida $s p$ sebanyak 9 sampel (19,5\%) dengan kepadatan berkisar 1-50 koloni (+), sebanyak 14 sampel (30,4\%) dengan kepadatan berkisar 50-100 koloni (++) dan 23 sampel (50,1\%) dengan kepadatan lebih dari Dari hasil pemeriksaan jamur Candida sp. pada 66 sampel swab rongga mulut perokok aktif di RW09 Komplek Kopersi Curug Cimanggis Depok berdasarkan Lamanya mengkonsumsi rokok seperti yang tercantum pada tabel 4:

Tabel 4

Hasil Pemeriksaan Terhadap Jamur Candida sp Pada Sampel swab rongga mulut perokok aktif di RW09 Komplek Kopersi Curug Cimanggis Depok berdasarkan lamanya mengkonsumsi rokok

\begin{tabular}{|c|c|c|c|c|c|c|}
\hline $\begin{array}{c}\text { Lama } \\
\text { Konsumsi } \\
\text { Rokok }\end{array}$ & $\begin{array}{c}\text { Jumlah } \\
\text { Yang } \\
\text { Diperiksa }\end{array}$ & $\begin{array}{c}\text { Positif } \\
\text { Candida } \\
\text { Sp }(\%)\end{array}$ & $\begin{array}{c}\text { Koloni } \\
+ \\
(1-50)\end{array}$ & $\begin{array}{c}\text { Koloni } \\
++ \\
(\mathbf{5 0}-100)\end{array}$ & $\begin{array}{c}\text { Koloni } \\
+++ \\
(>\mathbf{1 0 0})\end{array}$ & $\begin{array}{l}P= \\
\text { Value }\end{array}$ \\
\hline$<1$ Tahun & $\begin{array}{c}26 \\
(39,3 \%)\end{array}$ & $\begin{array}{c}14 \\
(21,2 \%)\end{array}$ & $\begin{array}{c}5 \\
(7,5 \%)\end{array}$ & $\begin{array}{c}5 \\
(7,5 \%)\end{array}$ & $\begin{array}{c}4 \\
(6,0 \%)\end{array}$ & $\begin{array}{l}\mathrm{X}^{2}= \\
0.024\end{array}$ \\
\hline$>1$ Tahun & $\begin{array}{c}40 \\
(60,7 \%)\end{array}$ & $\begin{array}{c}32 \\
(48,4 \%)\end{array}$ & $\begin{array}{c}4 \\
(6,0 \%)\end{array}$ & $\begin{array}{c}9 \\
(13,6 \%)\end{array}$ & $\begin{array}{c}19 \\
(28,7 \%)\end{array}$ & $\begin{array}{l}\mathrm{P}< \\
0.050\end{array}$ \\
\hline
\end{tabular}

Sumber: Safitri W ,2018

Dari tabel 4 diatas didapatkan hasil bahwa perokok yang mengkonsumsi rokok kurang dari satu tahun memiliki positif Candida sp sebanyak 21,2\% (14/26), dan memiliki kepadatan koloni yaitu + (150 koloni) sebanyak 7,5\% (5/14), ++ (50-100 koloni) sebanyak 7,5\% (5/14), dan +++ (>100 koloni) 
sebanyak 6,0\% (4/14). Sedangkan perokok yang mengkonsumsi rokok lebih dari 1 tahun memiliki positif Candida $s p$ sebanyak 48,4\% (32/40), dan memiliki kepadatan koloni yaitu + (1-50 koloni) sebanyak 6,0\% (4/32), ++ (50-100 koloni) sebanyak 13,6\% (9/32), dan +++ (>100 koloni) sebanyak 28,7\% (19/32). Dari hasil olah data dengan uji chi-square didapatkan hasil P- Value $0.024(\mathrm{P}<0,05)$ artinya terdapat hubungan yang bermakna antara keberadaan jamur Candida $s p$ dengan lamanya mengkonsumsi rokok.

Hasil pemeriksaan jamur Candida sp. pada 66 sampel swab rongga mulut perokok aktif di RW09 Komplek Kopersi Curug Cimanggis Depok berdasarkan banyaknya konsumsi rokok perhari seperti yang tercantum pada tabel 5:

Tabel 5

Hasil Pemeriksaan Terhadap Jamur Candida sp Pada Sampel swab rongga mulut perokok aktif di RW09 Komplek Kopersi Curug Cimanggis Depok berdasarkan banyaknya konsumsi rokok perhari

\begin{tabular}{ccccccc}
\hline $\begin{array}{c}\text { Banyak } \\
\text { Konsumsi } \\
\text { Rokok }\end{array}$ & $\begin{array}{c}\text { Jumlah } \\
\text { Yang } \\
\text { Diperiksa }\end{array}$ & $\begin{array}{c}\text { Positif } \\
\text { Candida } \\
\text { sp( }(\%)\end{array}$ & $\begin{array}{c}\text { Koloni } \\
+\end{array}$ & $\begin{array}{c}\text { Koloni } \\
++ \\
(1-50)\end{array}$ & $\begin{array}{c}\text { Koloni } \\
+++\end{array}$ & $\begin{array}{c}\mathrm{P}= \\
\text { Value }\end{array}$ \\
\hline 1 Batang & $\begin{array}{c}21 \\
(31,8 \%)\end{array}$ & $\begin{array}{c}11 \\
(16,6 \%)\end{array}$ & $\begin{array}{c}4 \\
(6,0 \%)\end{array}$ & $\begin{array}{c}2 \\
(3,0 \%)\end{array}$ & $\begin{array}{c}5 \\
(7,5 \%)\end{array}$ & $\mathrm{X}^{2}=0.037$ \\
& & & & & & \\
\hline$>1$ Batang & 45 & 35 & 5 & 12 & 18 & $<0.050$ \\
& $(68,2 \%)$ & $(53,0 \%)$ & $(7,5 \%)$ & $(18,1 \%)$ & $(27,2 \%)$ & \\
\hline
\end{tabular}

Dari tabel 5 diatas didapatkan hasil bahwa perokok yang mengkonsumsi rokok 1 batang perhari memiliki positif Candida sp 16,6\% (11/21) , dan memiliki kepadatan koloni yaitu + (1-50 koloni) sebanyak 6,0\% (4/11), ++ (50-100 koloni) sebanyak 3,0\% (2/11), dan +++ (>100 koloni) sebanyak 7,5\% (5/11). Sedangkan perokok yang mengkonsumsi rokok lebih dari 1 batang memiliki positif Candida sp sebanyak 53,0\% (35/45), dan memiliki kepadatan koloni yaitu + (1-50 koloni) sebanyak 7,5\% (5/35), ++ (50-100 koloni) sebanyak 18,1\% (12/35), dan +++ (>100 koloni) sebanyak 27,2\% (18/35). Dari hasil olah data dengan uji chi-square didapatkan hasil $\mathrm{P}$ - Value $0.037(\mathrm{P}<0,05)$ artinya terdapat hubungan yang bermakna antara keberadaan jamur Candida sp dengan banyaknya rokok yang dikonsumsi perhari.

Dari hasil pemeriksaan sampel jamur Candida sp. pada 66 sampel swab rongga mulut perokok aktif di RW09 Komplek Kopersi Curug Cimanggis Depok berdasarkan faktor perilaku kebersihan menyikat gigi seperti yang tercantum pada tabel 6 : 
Tabel 6

Hasil Pemeriksaan Jamur Candida sp pada sampel swab rongga mulut perokok aktif di RW09 Komplek Kopersi Curug Cimanggis Berdasarkan Faktor Perilaku Menyikat Gigi

\begin{tabular}{|c|c|c|c|c|c|c|}
\hline $\begin{array}{c}\text { Frekuensi } \\
\text { Menyikat } \\
\text { Gigi } \\
\text { Dalam } \\
\text { Sehari }\end{array}$ & $\begin{array}{c}\text { Jumlah } \\
\text { Yang } \\
\text { Diperiksa }\end{array}$ & $\begin{array}{c}\text { Positif } \\
\text { Candida } \\
\text { sp(\%) }\end{array}$ & $\begin{array}{c}\text { Koloni } \\
+ \\
(1-50)\end{array}$ & $\begin{array}{c}\text { Koloni } \\
++ \\
(50-100)\end{array}$ & $\begin{array}{c}\text { Koloni } \\
+++ \\
(>100)\end{array}$ & $\begin{array}{c}\mathrm{P}= \\
\text { Value }\end{array}$ \\
\hline $1 x$ & $\begin{array}{c}42 \\
(63,6)\end{array}$ & $\begin{array}{c}34 \\
(51,5 \%)\end{array}$ & $\begin{array}{c}7 \\
(10,6 \%)\end{array}$ & $\begin{array}{c}9 \\
(13,6 \%)\end{array}$ & $\begin{array}{c}18 \\
(27,2 \%)\end{array}$ & $\begin{array}{l}\mathrm{X}^{2}= \\
0.008\end{array}$ \\
\hline $2 \mathrm{x}$ & $\begin{array}{c}24 \\
(36,4 \%)\end{array}$ & $\begin{array}{c}12 \\
(18,1 \%)\end{array}$ & $\begin{array}{c}2 \\
(3,0 \%)\end{array}$ & $\begin{array}{c}5 \\
(7,5 \%)\end{array}$ & $\begin{array}{c}5 \\
(7,5 \%)\end{array}$ & $<0.050$ \\
\hline
\end{tabular}

Sumber: Safitri W ,2018

Pada tabel 6 hasil pemeriksaan didapatkan hasil pada perokok yang menggosok gigi 1 kali sehari positif Candida $s p$ sebanyak 51,5\% (34/42), dan memiliki kepadatan koloni yaitu + (1-50 koloni) sebanyak 10,6\% (7/34), ++ (50-100 koloni) sebanyak 13,6\% (9/34), dan +++ (>100 koloni) sebanyak $27,2 \%$ (18/34). Sedangkan pada perokok yang menggosok gigi 2 kali sehari positif Candida $s p$ sebanyak 18,1\% (12/24), dan memiliki kepadatan koloni yaitu + (1-50 koloni) sebanyak 3,0\% (2/12), ++ (50-100 koloni) sebanyak 7,5\% (5/12), dan +++ (>100 koloni) sebanyak 7,5\% (5/12) dari hasil Chi-Square didapatkan hasil $\mathrm{P}$ value $0.008(\mathrm{P}<0.05)$ artinya terdapat hubungan yang bermakna antara keberadaan jamur Candida sp di rongga mulut dengan faktor perilaku kebersihan menyikat gigi.

Dari hasil pemeriksaan sampel jamur Candida sp. pada 66 sampel swab rongga mulut perokok aktif di RW09 Komplek Kopersi Curug Cimanggis Depok berdasarkan keluhan pada perokok aktif seperti yang tercantum pada tabel 7:

Tabel 7

Hasil Pemeriksaan Jamur Candida sp Pada swab rongga mulut perokok aktif di RW09 Komplek Kopersi Curug Cimanggis Depok berdasarkan keluhan pada perokok aktif

\begin{tabular}{lcccccc}
\hline Keluhan & $\begin{array}{c}\text { Jumlah } \\
\text { Yang } \\
\text { Diperiksa }\end{array}$ & $\begin{array}{c}\text { Positif } \\
\text { Candida } \\
\text { sp(\%) }\end{array}$ & $\begin{array}{c}\text { Koloni } \\
+ \\
(1-50)\end{array}$ & $\begin{array}{c}\text { Koloni } \\
++ \\
(50-100)\end{array}$ & $\begin{array}{c}\text { Koloni } \\
+++ \\
(>100)\end{array}$ & $\begin{array}{c}\mathrm{P}= \\
\text { Value }\end{array}$ \\
\hline Ada & 40 & 33 & 3 & 11 & 19 & $\mathrm{X}^{2}=0.005$ \\
& $(60,6 \%)$ & $(50 \%)$ & $(4,5 \%)$ & $(16,6 \%)$ & $(28,7 \%)$ & \\
\hline Tidak & 26 & 13 & 6 & 3 & 4 & $<0.050$ \\
Ada & $(39,4 \%)$ & $(19,6 \%)$ & $(9,0 \%)$ & $(4,5 \%)$ & $(6,0 \%)$ & \\
& & & & & & \\
\hline
\end{tabular}

Sumber: Safitri W,2018 
Pada tabel 7 hasil pemeriksaan Candida sp. berdasarkan keluhan pada perokok keluhan yang terjadi yaitu adanya bercak putih pada rongga mulut, lidah terasa lebih peka terhadap makanan pedas dan panas. Perokok yang memiliki keluhan didapatkan positif Candida $s p$ sebanyak 50\% (33/40), dan memiliki kepadatan koloni yaitu + (1-50 koloni) sebanyak 4,5\% (3/33), ++ (50-100 koloni) sebanyak $16,6 \%(11 / 33)$, dan $+++(>100$ koloni) sebanyak 28,7\% (19/33). Sedangkan pada perokok yang tidak memiliki keluhan didapatkan positif Candida sp sebanyak 19,6\% (13/26), dan memiliki kepadatan koloni yaitu $+(1-50$ koloni) sebanyak 9,0\% (6/13), ++ (50-100 koloni) sebanyak 4,5\% (3/13), dan $+++(>100$ koloni) sebanyak 6,0\% (4/13). Dari hasil uji statistic dengan Chi-Square didapatkan hasil P value 0,006 ( $\mathrm{P}$ value $<0.05$ ) artinya terdapat hubungan yang bermakna antara keberadaan jamur Candida sp. dengan Adanya keluhan pada rongga mulut

Flora normal adalah mikroorganisme yang dianggap tidak berbahaya, pada rongga mulut terdapat banyak flora normal dalam keadaan tidak menimbulkan penyakit, namun bila terjadi gangguan sistem imun maupun perubahan keseimbangan flora normal rongga mulut maka flora normal tersebut dapat menjadi patogen.Salah satu flora normal di rongga mulut adalah Candida. (Kuswadji , (2006)

Pada penelitian ini membahas tentang Pemeriksaan Candida sp pada swab rongga mulut perokok aktif di RW09 Komplek Kopersi Curug Cimanggis Depok.Untuk keperluan tersebut diteliti dari hasil kuisioner responden kepada perokok aktif di RW09 Komplek Kopersi Curug Cimanggis Depok berdasarkan lamanya mengkonsumsi rokok, perilaku menggosok gigi dan keluhan yang terjadi. Pada penelitian ini didapatkan 66 sampel swab rongga mulut perokok aktif di RW09 Komplek Kopersi Curug Cimanggis Depok. Pemeriksaan ini dilakukan menggunakan 2 metode yaitu pemeriksaan langsung dengan Nacl 0,9\% dan dengan biakan $\mathrm{SDA}(+)$ untuk mengetahui koloni jamur Candida sp yang tumbuh.

Berdasarkan pemeriksaan langsung menggunakan Nacl 0,9\% didapatkan hasil bahwa dari 66 sampel swab rongga mulut yang diperiksa sebagian besar terdapat elemen jamur berupa sel ragi sebanyak 43 sampel $(65,1 \%)$ tidak ditemukan hifa semu 0\% dan tanpa elemen jamur sebanyak 23 sampel (34,9\%). Pada sampel swab rongga mulut juga dilakukan biakan pada media $\operatorname{SDA}(+)$ didapatkan hasil yaitu Candida sp 46 koloni (69,6\%), dan non Candida sp 20 koloni (30,4\%).

Berbeda dengan penelitian sebelumnya yang dilakukan oleh Ramadhani P pada tahun 2017 positif Candida pada 57 sampel sebanyak $(87,7 \%$ ) yaitu lebih banyak dari penelitian kali ini yaitu sebanyak $69,6 \%$ hal itu terjadi dikarenakan pada pemeriksaan yang dilakukan sebelumnya bahan pemeriksaan yang diambil hanya dari perokok yang sesuai dengan kriteria.

Pada hasil diatas ditemukan Candida $s p$ lebih banyak pada rongga mulut perokok aktif yaitu sebanyak $69,6 \%$, hal itu disebabkan karena perokok merupakan salah satu faktor predisposisi dalam terjadinya Candidiasis oral. Seseorang yang mengkonsumsi rokok selama hidupnya memiliki potensi yang cukup besar untuk terkena Candidiasis oral, rokok mengandung bahan toksik yang dapat 
menyebabkan perubahan kondisi rongga mulut seperti penebalan lapisan sel epitel, penngkatan perlekatan Candida, penurunan laju aliran, dan penurunan $\mathrm{pH}$ saliva. Kondisi tersebut mendukung pertumbuhan dan perkembangan kandida sehingga jumlah kandida menjadi lebih banyak yang kemudian dapat menyebabkan kelainan mulut.

Tidak ditemukannya elemen jamur pada 20 swab rongga mulut dapat disebabkan karena beberapa faktor, diantaranya lokasi pengambilan rongga mulut yang kurang tepat, elemen jamur Candida yang terdapat pada bahan yang dilihat di mikroskop dengan pemeriksaan Nacl $0,9 \%$ tidak terlihat, kurangnya kemampuan meneliti pada mahasiswa, sehingga mengakibatkan tidak ditemukan elemen jamur pada pemeriksaan.

Pada pemeriksaan biakan SDA (+) selain koloni Candida juga tumbuh jamur non Candida yaitu Aspergillus sp, Rhizopus, Penicillium, Culvularia, Mycelia sterillia. Aspergillus sp merupakan koloni kapang terbanyak. Koloni Candida $s p$ yang tumbuh kepadatannya sebanyak 9 sampel (19,5\%) dengan kepadatan berkisar 1-50 koloni (+), sebanyak 14 sampel (30,4\%) dengan kepadatan berkisar 50-100 koloni (++) dan 23 sampel (50,1\%) dengan kepadatan lebih dari 100 koloni .

Koloni diatas yang merupakan + (1-50 koloni ) masih merupakan flora normal yang ada pada mulut perokok , namun pada ++ (50-100 koloni) dan +++ (>100 koloni) bisa merupakan infeksi candidiasis oral pada rongga mulut perokok, akibat dari merokok menimbulkan terjadinya penebalan sel epitel pada rongga mulut sehingga Candida dapat membuat kolonisasi diantara lapisan lapisan sel epitel yang menebal tersebut.

Berdasarkan faktor kebiasaan merokok perokok aktif di RW09 menunjukan persentasi positif lebih banyak terinfeksi pada perokok yang mengkonsumsi rokok lebih dari satu tahun yaitu positif candida sebanyak 60,7\% (32/40), Dan kepadatan koloni pada perokok $>1$ tahun persentase tertinggi ada pada kepadatan koloni yaitu +++ (>100 koloni) sebanyak 28,7\% (19/32). Dari hasil tersebut menunjukkan semakin lama seseorang mengkonsumsi rokok semakin berpotensi terkena infeksi Candidiasis oral hal tersebut dapat dilihat dari persentase koloni terbesar ada pada perokok yang mengkonsumsi rokok lebih dari satu tahun yaitu $+++(>100$ koloni) pada rongga mulut perokok aktif yaitu sebanyak 28,7 (19/32). Hasil analisis bivariate dengan uji Chi-square antara hubungan lamanya mengkonsumsi rokok terhadap jamur Candida sp pada rongga mulut perokok didapatkan hasil $\mathrm{X}^{2}=0,024(\mathrm{P}<0,050)$ artinya ada hubungan bermakna lamanya mengkonsumsi rokok dengan keberadaan jamur Candida sp pada rongga mulut .

Berdasarkan perokok yang mengkonsumsi rokok persentasi positif lebih banyak pada perokok yang mengkonsumsi rokok lebih dari satu batang perharinya yaitu memiliki positif Candida sebanyak $53,0 \%$, dan persentasi kepadatan koloni tertinggi ada pada perokok yang mengkonsumsi rokok lebih dari 1 Batang perhari yaitu +++ (>100 koloni) sebanyak 27,2\% (18/35). Hasil tersebut menunjukkan semakin banyak seseorang mengkonsumsi rokok perhari semakin berpotensi terkena infeksi 
Candidiasis oral hal tersebut dapat dilihat dari persentasi terbesar kepadatan koloni ada pada orang yang mengkonsumsi rokok lebih dari satu batang perhari yaitu pada koloni +++ (> 100 koloni) 27,2 (18/35). Hasil analisis bivariate dengan uji Chi-square antara hubungan banyakya konsumsi rokok terhadap jamur Candida sp pada rongga mulut perokok didapatkan hasil $\mathrm{X}^{2}=0,037(\mathrm{P}<0,050)$ artinya ada hubungan bermakna Banyaknya konsumsi rokok dengan keberadaan jamur Candida $s p$ pada rongga mulut .Karena semakin lama dan semakin banyak perokok tersebut mengkonsumsi rokok semakin besar kemungkinan Iritasi yang terus menerus dari hasil pembakaran tembakau menyebabkan penebalan pada jaringan mukosa mulut tersebut karena itu hal yang ditimbulkan tersebut dapat berpotensi menimbulkan tumbuhnya jamur pada mulut perokok aktif. (Mulyawati, Y, 2010 ).

Berdasarkan faktor perilaku menyikat gigi perokok aktif di RW09 menunjukan presentase positif Candida $s p$ lebih banyak terinfeksi pada perokok yang menyikat gigi 1 kali sehari yaitu $51,5 \%$, dan Kepadatan koloni dengan persentase tertinggi yaitu $+++(>100$ koloni) yaitu sebanyak 27,2\% $(18 / 42)$. Hal tersebut disebabkan semakin sedikit frekuensi menyikat gigi dalam sehari semakin berpotensi menyebabkan terjadinya Candidiasis oral, Selain karna merokok faktor kebersihan mulut yang tidak terjaga juga dapat menimbulkan timbulnya jamur Candida $s p$ pada rongga mulut perokok tersebut . Menggosok gigi 2 x sehari dapat mengurangi kemungkinan terjadinya terkena Candidiasis oral karena jika kebersihan mulut terjaga yaitu dengan menggosok gigi secara teratur maka kemungkinan terjadinya penumpukan sel epitel semakin sedikit sehingga jamur Candida tidak berkolonisasi dengan banyak di rongga mulut tersebut. Analisis bivariate dengan uji Chi-square antara hubungan faktor perilaku menyikat gigi perokok aktif dengan keberadaan jamur Candida $s p$ pada rongga mulut perokok didapatkan $\mathrm{X}^{2}=0,010(\mathrm{P}<0,050)$ artinya ada hubungan bermakna antara faktor perilaku menyikat gigi terhadap keberadaan jamur Candida sp pada rongga mulut perokok.

Berdasarkan Keluhan yang terjadi pada perokok menunjukan presentasi positif jamur Candida lebih banyak terinfeksi pada perokok yang memiliki keluhan yaitu sebanyak 50\%, dengan kepadatan koloni dengan persentase tertinggi yaitu $+++(>100$ koloni) sebanyak $28,7 \%$ pada perokok yang memiliki keluhan. Dari hasil diatas perokok yang memiliki keluhan lebih tinggi persentasenya hal ini disebabkan karena perokok yang memiliki keluhan berpotensi terinfeksi Candidiasis oral bisa dilihat dari kepadatan koloni yang tumbuh pada media perokok yang memiliki keluhan persentase tinggi pada $+++(>100$ koloni) yaitu sebanyak 28,7\% . Dari hasil diatas Hasil analisis bivariate dengan uji Chisquare antara hubungan Keluhan yang terjadi pada perokok dengan jamur Candida yaitu 0,006 $(\mathrm{P}<0,050)$ artinya ada hubungan bermakna antara keluhan yang terjadi pada perokok terhadap keberadaan jamur Candida $s p$ di swab rongga mulut. 


\section{SIMPULAN}

Persentase keberadaan Candida sp pada rongga mulut perokok aktif pada biakan SDA+ didapat $46(69,6 \%)$ sampel positif Candida sp. Terdapat hubungan bermakna antara keberadaan Candida sp pada rongga mulut perokok aktif dengan lamanya jangka waktu mengkonsumsi rokok $\mathrm{p}=0.024$, Terdapat hubungan bermakna antara keberadaan Candida $s p$ pada rongga mulut perokok aktif dengan banyaknya konsumsi rokok perharinya $p=0.037$, Terdapat hubungan bermakna antara keberadaan Candida sp pada rongga mulut perokok aktif $\mathrm{d}$ dengan perilaku menyikat gigi $\mathrm{p}=0.008$, dan Terdapat hubungan bermakna antara keberadaan Candida sp pada rongga mulut perokok aktif dengan Adanya keluhan yang terjadi pada perokok $\mathrm{p}=0.005$.

\section{UCAPAN TERIMA KASIH}

Penulis mengucapkan terima kasih kepada Prodi D III Analis Kesehatan Fakultas Kesehatan Universitas MH Thamrin. dalam penelitian ini.

\section{DAFTAR PUSTAKA}

1. Adimoelja, A. (2000) 'Phytochemicals and the breakthrough of traditional herbs in the management of sexual dysfunction Aditama T.Y (1997). Rokok dan Kesehatan . Jakarta : Universitas Indonesia

2. Calcaterra R, Pasquantonio G, Vitalli LA, Nicolleti M, Di Girolamo M, Mirisola C, Prenna M , Condo R, Baggi L ( 2013 ) Occurrence of Candida species colonization in a population of denture-wearing immigrants. Int J Immunopathol Pharmacol candidiasis. Journal Microbiol.

3. Direktorat Jendral Pengendalian Penyakit Menular dan Penyehatan Lingkungan (2005) http://p2p.kemkes.go.id/sakip-direktorat-pencegahan-dan-pengendalian-penyakit-menularlangsung/ diaskes pada 8 juni 2018

4. Ellepola, A.N., dan Morrison, C.J. 2005. Laboratory diagnosis of invasive

5. Husaini tobat merokok depok : Pustaka Iman , 2006

6. Krisno, Agus. 2011. Anatomi Dan Morfologi Bakteri, Jamur dan Virus. http://Pondok Ilmu.html. diaskes pada 2 juni 2018

7. Kuswadji. Kandidosis. Dalam : Djuanda A., Hamzah M., Aishah S., Ilmu Penyakit Kulit dan Kelamin. Edisi IV, Balai Penerbit Fakultas Kedokteran Universitas Indonesia, Jakarta, 2006. Pp:103-6

8. Lewis MAO, Lameg P.J 1998 , tinjauan klinis penyakit mulut / Clinical oral medicine . Jakarta

9. Lynch M.A Brightman VJ \&Greenberg M.S Ilmu Penyakit Mulut Jakarta : penerbit Binarupa aksara , 1999

10. Mulyati Sulaeman, JR,Susilo, J parasitologi Kedokteran Fakultas Kedokteran UI, edisi keempat

11. Mulyati, Penuntun Praktium Mikologi, Jakarta, 2014.

12. Mulyati. Identifikasi Jamur. Jurnal Mikologi Kedokteran Indonesia, 2000.

13. Mikrobia.files.wordpress.com diaskes pada 2 juni 2018 
14. Nasution ,I.K perilaku merokok pada remaja tesis master tidak diterbitkan, Univ Sumatera utara, medan , Indonesia , 2007

15. R, Panjarathinam, Pracical Medical Microbiology, 2009

16. Riset Kesehatan $\quad$ Dasar $\quad 2010 \quad 2013$ http://www.depkes.go.id/resources/download/general/Hasil\%20Riskesdas\%202013 diaskes pada 5 juni 2018

17. Sutiyoso PPRI No 19 TAHUN 2003 tentang pengaman rokok bagi kesehatan, 2004

18. Suprihatin, Candida dan kandidiasis pada manusia, FKUI , 1982

19. Tjokronegoro, Arjatmo Utama, Hendra Dermatomikosis superfisialis, PERDOSKI: penerbit fakultas kedokteran UI , 2001

20. Warnakulasuriya S., Dietrich T., Bornstein M., Peidró E., Preshaw P., Walter C., Wennström J., and Bergström J. Oral health risks of tobacco use and effects of cessation. International Dental Journal 2010. 60:7-30

21. Yenny Mulyawati, MS. Departemen kesehatan RI http:/dokternasir.web.id/2009/03pengaruhrokok-terhadap-kesehatan.htmldiaskes pada 2 juni 2018 